The Turkish Online Journal of Design, Art and Communication - TOJDAC

ISSN: 2146-5193, September 2018 Special Edition, p.990-997

\title{
MORALITY AS THE MYSTERY OF METAPHYSICS: DOSTOEVSKY'S AND NIETZSCHE'S VERSIONS
}

\author{
Tamara Sergeevna KUZUBOVA \\ Ural Federal University named after the first President of Russia B.N. Yeltsin, Russia \\ Nadezhda Petrovna TSEPELEVA \\ Ural Federal University named after the first President of Russia B.N. Yeltsin, Russia
}

\begin{abstract}
A comparative analysis of the main conceptual moments of F.M. Dostoevsky's and F. Nietzsche's versions of destruction of metaphysics as a moral interpretation of the world is conducted. Metaphysics is subverted as a world interpretation of a "good" (Nietzsche) and "direct" (Dostoevsky) person. The destruction of metaphysics as a moral interpretation of the world results in the opposite projects of overcoming moral in "supermoral" offered by Dostoevsky and Nietzsche, and classical metaphysics - in nonclassical versions of interpretation of the world in which the irrational will appear as its main line.
\end{abstract}

Keywords: Metaphysics, Morality, Destruction, Transcendental, Genealogy, Interpretation, "Good Man", "Underground Man", "Strengthened Consciousness"

\section{INTRODUCTION}

According to Jaspers, Dostoevsky and Nietzsche belong to thinkers who designated the "spiritual threshold" of the modern era ${ }^{1}$. Having overcome and comprehended the crisis of humanism and the rise of nihilism as personal experience, as well as the fate of Europe and Russia, they reassessed all the values that marked the "radical change of the human existence itself" (Jaspers, 1994: 241). The heart of this reassessment was the discovery of the essence of morality, which the German thinker considered his epoch-making accomplishment, proclaiming future catastrophes in all spheres of life of a European person. This proclamation is also the "nerve" of Dostoevsky's works. The events of the "death of God" and "the death of an ethical subject" (Horuzhii, 2007: 87) are inextricably linked and appear not only as a philosophical problem, but primarily as an urgent problem of human existence. Metaphysics as the science of the supersensible principles of existence is always meta-physics, transcendence, the emergence of thought beyond the limits of experience, the current being and the creation. The radical elimination of the transcendental, "meta-", undertaken during the destruction of classical metaphysics, revealed the immanence of the world, in which a human had to build his existence from now on. Since the end of the 19th century, European conception had sought the path away from the abyss of the "silence of being" (Buber, 1995), which devoured human existence, to a new discovery of being and meaning, as well as to the new opportunities of life. Taking into account the peripeteia of the history of metaphysics in the 20th century, the most radical projects, which overcame it, turned out to be the recognition of the impossibility of its complete elimination from the philosophical language and the European culture. In modern philosophy, the possibility of reviving metaphysics after Nietzsche is discussed, and ethics is engaged in the formation of nonclassical discourse in the situation of "rejecting all the essentialist's positions" (Horuzhii, 2007: 7). A new "breakthrough to the transcendent" (Gaidenko, 1997) in philosophy and the emergence of a nonclassical ethical discourse contribute to a necessity for conducting a comparative analysis of the conceptual foundations of classical and nonclassical discourse in metaphysics. In this connection, in our view, it is considered important to comprehend once again the impressive pivotal experience of destruction (understood in Heidegger's sense) of European metaphysics, performed almost simultaneously by Dostoevsky and Nietzsche. In this experiment, the leitmotif is the deposition of metaphysics as a world moral interpretation. The aim of the article is to compare the key motives of the above-mentioned destruction in the works of Dostoevsky and Nietzsche. Undoubtedly, Dostoevsky obtains the superiority in the artistic metaphysical interpretation of the phenomenon of nihilism as a "disease" of European humankind, but it was Nietzsche who created its detailed philosophical concept 
(Heidegger, 1993: 63-64). From this point of view, it seems legitimate to commence the consideration of the key conceptual moments of the destruction of metaphysics as a moral interpretation according to Nietzsche, and to compare it with the main motives of Dostoevsky's version in the course of further analysis.

\section{THE SYMBIOSIS OF REASON AND MORALITY AS THE SOURCE OF METAPHYSICS}

For Nietzsche, metaphysics is the interpretation of existence that prevailed for two millennia, the commencement of which was launched by Plato due to the invention of a supersensible world of ideas, towering above the sensory world of becoming; the quintessence of this world interpretation is embodied in Christianity. According to Nietzsche, the figment of the metaphysical world rests on faith in morality, which acts as the hidden basis and goal of all philosophical structures. "Since Plato's time, philosophy is possessed by morality" (Nietzsche, 2005: 238). The task of the new philosophers is to destroy the moral foundation of the majestic philosophical buildings, since trust in reason and faith in the truth are moral phenomena. The identity principle of thinking and being appears to be a moral prejudice and a consequence of the identification of truth and well-being. "That thinking serves as a measure of reality - such a view is crude non plus ultra of moral credence (to the original principle of truth, which is the basis of all things) ..." (Nietzsche, 2005: 256). Morality said "yes" to the truth and to the true world and "no" to Nietzsche's apparent world, revealing the mystery of the symbiosis of reason, the instinct of cognition that generates metaphysics, as well as morality. The metaphysical mind is originally moral. A philosopher, obsessed with the will to know the truth, as Deleuze observes, is a truthful person. "A person, who does not want to deceive and wants a better world and a better life; all the arguments in favor of not deceiving are moral reasons" . Reason that opposes sensual perception and appearance reveals a true, supersensible world. "A plausible world is inseparable from... the will to view this world as an appearance of it. If this is so, the opposite of cognition and life, as well as the difference between the worlds, reveals its true nature: it is a question of the difference of moral origin, of the opposite of the moral character" (Deleuze, 2003: 202). Morality is the requirement that "it should be so" and "the point of view of desirability" (Nietzsche, 2005: 197), which includes a judgment about the existence and its scrutiny. Evaluating the world in which he or she lives as undue and untrue, a philosopher is inventing the world to be "how it should have been", and hence, a genuine, true world. Consequently, morality is always a certain interpretation of human life and the existence in general, corresponding to human needs. Being influenced by morality, metaphysics interpreted the moral opposites in the "text and essence of affair" (Nietzsche, 1990, 2: 280). "... "The true world" was built from a contradiction to the real world - that is actually an apparent world, because it is only a moral and optical fraud" (Nietzsche, 1990, 2: 571).

The abolition of the true world requires the abolition of morality, which Nietzsche implements by means of a genealogical method, designed to answer the question: who is interpreting? Who speaks within the context of morality and metaphysics? Morality turns out to be the interpretation of existence that meets the needs of a "good person" (Nietzsche, 2005: 208). A person is confident in the existence of the true world and its opposition to an apparent, untrue and undue world. The psychological ground of the faith in the true world and in existence is distrust in becoming, fear of time, deception and death. A "good person", wishing to get rid of them, "inflates his or her needs to the size of cosmic and metaphysical values" (Nietzsche, 2005: 40). Thus, "the psychology of metaphysics" (Nietzsche, 2005: 323 ), according to Nietzsche, is the psychology of a "good person". Nevertheless, since "life itself is appreciated through us" (Nietzsche, 2: 576), then any interpretation is inspired by some kind of life. Metaphysics as morality, taking the position of condemnation of life, can only be a symptom of a tired and descending life. Ressentiment, the "instinct of revenge and rancor" lies at the heart of the morality of a "good person" (Nietzsche, 2005: 217), the powerless will of a suffering and mediocre human type. A "good person" appears to be a tyrant. The conditions of his or her existence, embodied in morality a world "existing beyond all suffering" (Nietzsche, 2005: 200) - he or she makes it the scale of life, prescribing it to the world as a law. A distinctive feature of a "good person" is "hyperbolic naivety": the habit of "assuming oneself as a meaning and a measure of things' value..." (Nietzsche, 2005: 35). The vice of this naivety, as Heidegger highlights, is not in the humanization of things, but the fact that it is carried out unconsciously. "A "good person" of this "morality", thinking metaphysically, is the person who does not know anything about the origin of values, to which he or she subordinates as unconditional ideals" (Heidegger, 1993: 107). Accepting the highest values as the gift of the existence, a "good person" finds his or her true purpose in obedience. Therefore, he or she appears to Nietzsche 
not only as a tyrant, but at the same time as an "ideal slave". "The ideal slave ("good person"). The one who cannot think of himself or herself as a "goal" and, in general, is not able to create goals, he or she inclines to the morality of self-denial - instinctively" (Nietzsche, 2005: 212). The naive exaggeration of one's own value, achieved in a paradoxical way through renunciation of oneself and approaching to an ideal scale, single for all, is the secret of a "good person". But in morality there is a strong antidote for despair, "for leaping into Nothing" and for nihilism. A "good person" created the supersensible world as an "infinitely valuable whole" (Nietzsche, 2005: 34) to "... have the ability to believe in one's own value" (Nietzsche, 2005: 34). The moral of the good as a metaphysical world interpretation determined the destinies of European humanity and, ultimately, gave rise to nihilism. The imagesymbol of a "good person" according to Nietzsche, however, is not unambiguous. Beliefs in the true world are supported not only by the "incurably mediocre" (Nietzsche, 1990, 2: 387), but also by "higher persons" (Nietzsche, 1990, 2: 206), or the "sublime" ones (Nietzsche, 1990, 2: 83). In contrast to a "good person", they are endowed with "strengthened consciousness" and they are not characterized by a naive, unconcerned belief. Unable to live a lie, they realize the inconsistency of life with higher values and inevitably become pessimists. However, they are searching for hope in the past, trying to save the true world. The type of a "higher man" is presented in Nietzsche's books by a scientist, philosopher and distinguished representatives of "homines religiosi" (Nietzsche, 1990, 1: 671). Socrates, Pascal, Kant, Schopenhauer, Wagner personify the type of a "higher man".

Metaphysics draws the conclusions of a "good person", which are inspired by suffering, which is its starting point. Philosophers - sublime ones - by closing their eyes on the origin of the metaphysical true world due to the psychology of a "good person" affirm the unconditional morality. This unconditionality is illusory and rests on the affirmation of the transcendental source of morality. "From a philosophical point of view, morality establishes itself as the ability of reason; it is not established at the expense of deducing it from something else, but due to the fact that it mentally realizes its origin from the supersensible human essence..." (Jaspers, 2004: 223). Created by the efforts of reason, the true world acquires the character of obligation in relation to life and prescribes obedience to a person. This circumstance is indicated by Heidegger: "If "truth", i.e. the true and the real, is deduced and erected in a self-existent world, then this truly existent acts as something that the human life must yield to. The truth is in itself due and desired" (Heidegger, 1993: 105). The symbiosis of reason and morality reaches its apogee in Kant's works. He is the philosopher whom Nietzsche considers to be the ultimate incarnation of the "sublime" type. Commenting on Nietzsche's position, Deleuze notes that in a situation where a person no longer wants to obey God, the state, or his parents, the sense preserves the inviolability of its position as the highest authority and convinces us "...to preserve obedience, for he says: You command yourself" (Deleuze, 2003: 196). At the same time, Kant's philosophy represents a pivotal moment in the history of metaphysics; it appears in the Twilight of the Idols as the final stage in the evolution of idea of the true world, leading to its self-abolition (Nietzsche, 1990, 2: 572). Outlining the boundaries of pure reason, Kant actually indicates the unreasonable nature of moral demands. With the help of criticizing pure reason, as Nietzsche asserts, Kant managed to make his moral kingdom inaccessible to the attacks of reason. Insisting on the self-righteousness of the moral mind, nevertheless, he invented a transcendental world of higher values, to the rank of which he promoted the irrational dictates of the heart - the "unreachable, unprovable, not able to be promised" world (Nietzsche, 1990, 2: 572). Following Nietzsche, Adorno shows that the intent of the critique of practical reason is the salvation of the "positivity of mundis intelligibilis" (Adorno, 2011: 506). In its study, Kant, "like no other philosopher, presented ... human (humane) and transcendent conjuncture" (Adorno, 2011: 506, 514).

The most important aspect of Nietzsche's destruction of metaphysics as a moral interpretation of the existence is the destruction of the conviction in the unconditionality and the transcendental origin of morality. The moral reason itself, in its historical development, under the name "intellectual conscience" (Nietzsche, 1990, 1: 515) comes to the necessity of such destruction, to the discovery of the essence of morality. Nietzsche's notion of intellectual conscience once again points to the initial bond of reason and morality. Intellectual conscience as an attribute of new philosophers, "free minds" (Nietzsche, 1990, 1: 233) is a legacy of the demand for unconditional truthfulness, brought up by Christianity in a European person. As Jaspers notes, "the very criticism of morality derives from morality, heightened to the limit" (Jaspers, 2004: 228). Heidegger states that the reappraisal of all values arises "from an unambiguous awareness of phenomena" (Heidegger, 1993: 91) and, therefore, 
"the new reliance of values should have its origin in a new and strengthened consciousness (calculation)" (Heidegger, 1993: 91). (Obviously, the concept of "strengthened consciousness" is not used here accidentally, since in the works of Dostoevsky, whose name Heidegger mentions at the very beginning of "European nihilism", it is the most important characteristic of the nihilist characters). The mind turns against reason, morality revolts against morality. The intellectual conscience of a philosopher, a free mind, first of all requires to overcome the "good person" in himself, to produce "vivisection over the "good person", over "homo bonae voluntatis"... over himself!" (Nietzsche, 1990: 341).

Finding morality in the origins of metaphysics, and a "good person" in the sources of the last psychological needs, transfers morality from the true self-existent world to the world of phenomena, depriving it of its connection with the transcendent. It ultimately shatters the illusion of true being. Discovering the will to Nothing behind the moral interpretation, the philosopher comes to a conclusion: morality is a particular case of "the fundamental immorality of all that exists" (Nietzsche, 2005: 195), and the truth is a particular case of error. Nietzsche's classical metaphysics is opposed by the anti-metaphysical "philosophy of becoming"; its essence "lies in an absolutely unethical vision" (Ricoeur, 2008: 611). Heidegger draws attention to the dual understanding of morality, according to Nietzsche. On the one hand, morality is a collection of former higher values, in which a "good person" finds the goal of his life. On the other hand, morality means a system of assessments, rooted in the living conditions of human existence. According to Nietzsche, the life itself is a requirement that "it should be so": "the point of view of desirability, illegal game in court is the belonging of the course of things" (Nietzsche, 2005: 197). The root of morality is not in Kant's reasonable "goodwill", but in an irrational will to power. Using the expression of Kierkegaard, this approach can be called the elimination of the ethical (although, according to the Danish philosopher, this elimination had a different meaning). According to Jaspers's remark, the reduction of morality to the will to power hides a specific sense of ethics. In fact, morality is one of the guises of the will to power, one of the means of interpretation. It would seem that eliminating the ethical leads to "radical nonobligatoriness" (Jaspers, 2004: 241) and arbitrariness, but Nietzsche's immortality does not mean the justification of the out-of-moral "simple life" (Jaspers, 2004: 242). The thought of Nietzsche, who affirms the immanence of life, reveals a desire to transcend the phenomenal world. Hence the project of overcoming morality in supermorality emerges, the imperative of which is "creativity as freedom without transcendence" (Jaspers, 2004: 240).

\section{"STRENGTHENED CONSCIOUSNESS" AGAINST "SELF-EVIDENCE" OF REASON AND MORALITY}

In Dostoevsky's work, there is no consciously declared program of destruction of "the entire former world view" (Dostoevsky, 1972-1990, 15: 83). However, the philosophical discoveries of Dostoevsky and Nietzsche are undoubtedly comparable in their scale. The writer comprehended the epoch-making phenomenon of nihilism, creating, in fact, an artmetaphysical world of a nonclassical type, forestalling the search for European philosophical thought. "The theory of knowledge, ethics and ontology - the whole philosophy is constructed in a completely different way for someone who will accept "dedication" from Dostoevsky..." (Shestov, 1993: 91). The task of overthrowing the "entire former worldview" was primarily laid on the character of "Notes from the Underground", a work that marked the turn in Dostoevsky's world outlook. L. Shestov considered Notes as a genuine criticism of pure reason, the task of which was "to overcome the order of ideas that Hegelian philosophy embodied in itself as a result of the development of European thought" (Shestov, 1992: 15). "The Underground Man" is one of the main "conceptual characters" of Dostoevsky, the first in the series of nihilist heroes, a person who is extremely conscious. He does not know the "real life" (Dostoevsky, 1972-1990, 5: 178), consciously choosing life in the "underground" (Dostoevsky, 1972-1990, 5: 104) as opposed to the fake existence in the world of "direct people and personalities" (Dostoevsky, 1972-1990, 5: 101). There is an obvious parallel between the "underground man" and the "dungeon dweller" from Nietzsche's "The Daybreak". These conceptual characters have the same task - "undermine" the foundation of the grand philosophical buildings, erected for centuries. The metaphor of "descent into the depths" in the works of both Dostoevsky and Nietzsche is the designation of the way to destroy 
the true world, the way of thinking that finds in the motive of higher values the irrational element of will.

The main motive for the destruction of the former interpretation of the world, undertaken by the "underground man", is the same as that of Nietzsche: the discrepancy between the demands of the mind that legitimized the claim of morality, and the reality, suspicion of heightened consciousness regarding the insincerity of the true world. The distinctive trait of the "underground man", similar to other Dostoyevsky's nihilist characters, is the combination of strengthened consciousness with the "need of a higher thought" (Dostoevsky, 1972-1990, 24: 334) and a higher life, with a thirst for truth, harmony and meaning. Nietzsche's characteristic can be rightly attributed to it: "Pessimists are rebels, driven by moral pathos. Morality as the reason for pessimism. Pessimism as the forerunner of nihilism" (Nietzsche, 1990: 187). The main argument in the destruction of the "fundamental metaphysical system" (Heidegger) is suffering, which unequivocally testifies to the lack of harmony and meaning in the world and causes it to be condemned, and at the same time to question the highest values. Plato's world of truth, goodness and beauty in the reasoning of the "underground man" is transformed into a "stone wall". "What is a stone wall?" Well, of course, the laws of nature, the conclusions of natural sciences and mathematics" (Dostoevsky, 1972-1990, 5: 105). The "stone wall" is not only a metaphor for the immutable laws of nature established by science, but also for the norms of morality, acting as discovered (Shestov, 1992: 22) and "forced" truths. According to Dostoevsky, the sense of criticism of the former systems of ideas is as follows: "So the mind has proved to be insolvent in front of reality, yes, moreover, scientists, being sensible, themselves begin to teach now that there is no argument for pure reason, that pure reason does not even exist in the world... that there are minds of Ivan, Petr and Gustave, but there was no pure reason at all; that this is only an unfounded invention of the eighteenth century" (Dostoevsky, 1972-1990, 5: 78). "Mathematics" and "twice two makes four" (symbols of the "law of reasonable necessity" (Dostoevsky, 1972-1990, 24: 171) invade the sphere of human existence. Science, which explains to a person that "he or she has no will or whim at all" (Dostoevsky, 1972-1990, 5: 112), and utilitarian ethics that justifies the necessity of virtue, unite in the mind of "underground man" into one single piece. The symbolic embodiment of the realm of prudence, the triumph of the union of reason and morality is the image of the "crystal palace" (Dostoevsky, 1972-1990, 5: 113), which has a clear resemblance to Kant's "majestic moral buildings" (Nietzsche, 2010: 7) from the foreword to Nietzsche's "Daybreak" (Luft \& Stenberg, 1991: 448).

The strengthened consciousness of a nihilist, encouraged by moral pathos, underlies the destruction of the mind's self-evidence, contrasting it with life as figments - "the continuity of the process of achievement" (Dostoevsky, 1972-1990, 5: 118) and the will as its quintessence. The "underground man" clearly sees that the "stone wall" is "not a word for the world" (Dostoevsky, 1972-1990, 5: 106) (according to Nietzsche, it is just an interpretation, not the text). All philosophical theories that justify the inevitability of a "crystal palace" are "only logistics" (Dostoevsky, 1972-1990, 5: 111); perhaps, the very crystal building itself is just an illusion. Moral reflection plays a special role in overthrowing the "true world". Reflection on the cause, possibility and moral justification of an action goes into a bad infinity and "reasons evaporate" (Dostoevsky, 1972-1990, 5: 108). "The underground man" asks: "But how, for example, will I calm myself down? Where do I have the initial reasons, on which I can rest on, where are the grounds? "(Dostoevsky, 1972-1990, 5: 108). The result of such strengthened consciousness is "...the destruction of faith in general rules. "There is nothing sacred" (Dostoevsky, 1972-1990, 16: 330). The only reality is a baseless and aimless formation: the "dark stagnation" of nature and the "absurdity of the whole historical reality" (Dostoevsky, 1972-1990, 30(1):163). Hence, there is a negative assessment of philosophy, the highest subject of which has always been the existence. Here is the judgment from the draft materials from "The Adolescent": "Philosophy... it is something about the laws of things' existence, and the existence must be indispensable and, in any case, higher than the human mind, for the single purpose that for the whole life, a person sought to define it and could not do it. Moreover, it is vital that a person could never find anything in the existence: this is more decent, and that is the task. So to speak, this is the highest game of blind man's 
buffs - well, that is all" (Dostoevsky, 1972-1990, 16: 286). In this evaluation, the meaning of the destruction of metaphysics in Dostoevsky's option is concentrated: the metaphysical, true world is unattainable for human understanding. The search for being, which is identical with the well-being, does not lead anywhere - the highest truth that gives a meaning to human life is a figment, only "the highest game in blind man's buffs". The same can be found in Nietzsche's works: "...The nature of being is not "true", but false ... eventually, there is no more reason to convince oneself of the existence of the true world ..." (Nietzsche, 2005: 35).

The illusion of the true world, intelligent and good existence, fully meets the aspirations of the "direct person" (Dostoevsky, 1972-1990, 5: 104). This is a conceptual character, similar to Nietzsche's "good person", the antipode of the intensely conscious "underground man". In contrast to the latter, forced to abandon the reason's self-evidence and live without former moral supports, the "direct person" is "positively defined" (Dostoevsky, 1972-1990, 5: 109). His vital role and rules are worked out once and for all. Strengthened consciousness that rejects the unbiased and immoral world is directed to the eternally unattainable and unconditioned, and the mediocre man already has it. The very epithet "direct" indicates a distinctive feature of this psychological type -consciousness, which is not burdened with reflection and moral doubts. The unconditional of "direct people and personalities" is a "stone wall", in front of which they "give in with all sincerity" (Dostoevsky, 1972-1990, 5: 103). Dostoevsky gives a key characteristic of the psychology of the "direct person" and the world interpretation that inspired it: "The wall has something restful for them ["direct people"], morally resolving and final, perhaps even something mystical..." (Dostoevsky, 1972-1990, 5: 103-104). For them, the "stone wall" is a "word for the world": rationality and moral order are inherent to the existence; and therefore "direct people" find in the "stone walls" a solid foundation for their actions. That is why the "wall" contains something "morally resolving": the reason justifies the morality of the "direct person", helps to "count the benefits" (Dostoevsky, 1972-1990, 5: 110) and identify one's benefit with virtue. The psychology of the "direct person" who sincerely passes before the "stone wall" (let us recall, according to Nietzsche: "a good man is an ideal slave"), is discovered by the "underground man" in the foundations of science, the ethics of a reasonable egoism, as well as in theories of historical progress. And here is the same belief in the mind, inherent in the existence, the naïve attribution of the real history of all sorts of "desires". The thinker, convinced that a good beginning retriumphs in an enlightened person, is viewed by the hero of the "Notes" as the same "direct person". "Oh, baby! Oh pure, innocent child!" - exclaims the "underground man" (Dostoevsky, 1972-1990, 5: 110). This means the same "hyperbolic naivety", which, according to Nietzsche, distinguishes a "good person" - the ability to inflate one's own needs to cosmic, metaphysical dimensions. The habit of viewing the mind as the measure of reality and human existence forces thinkers, for the sake of logic, to turn a blind eye on the apparent irrationality of history and to foresee the triumph of reason and humanity in the historical process. It also induces science to exclude will, an irrational "whim" (Dostoevsky, 1972-1990, 5: 113) and the chance from the systems and classifications and replace it with "logistics". This is the reason why the properties of a "direct person" appear in the philosophical theories as the definitions of a human in general, the "son of nature." However, "l'homme de la nature et de la vérité" (Dostoevsky, 1972-1990, 5: 104) is not at all a norm, but a figment, just a projection of the psychology of a "direct person". "You believe in l'homme de la raison, in l'homme de la nature et de la vérité and do not notice that he is a doll that does not exist" (Dostoevsky, 1972-1990, 20: 203). The "direct person", under the guise of "l'homme de la nature et de la vérité" according to Dostoevsky, as well as to Nietzsche, appears to be a tyrant. Despotism is seen by the "underground man" in philosophical theories, seeking to confine a human being within the framework of reason and goodwill. Thus, in Dostoevsky's world, there are its "sublime" ones, actually engaged in the metaphysical justification of the normal interests of the "direct person". We refer to an interesting article by Elthaninoff, who claims that Dostoevsky creates his own psychological and ethical theory of justice (Elthaninoff, 2011). Based on the example of the trial of Dmitri Karamazov, the author shows how a writer exposes the alliance of scientific reason represented by naturalistic psychology, repressive morality and unfair justice. Rejecting the reductive approach to a human, Dostoevsky contrasted "scientific" psychology with a kind of profound psychology, taking into account the integrity of human 
existence. "For Dostoevsky, the path to the moral life of people lies through psychology..." ("Pour Dostoïevski, atteindre la vie morale des individus passe par la psychologie...") (Elthaninoff, 2011:84).

\section{CONCLUSION}

Dostoevsky's characters-nihilists, possessed by the will to the truth, destroy the classical unity of truth, goodness and beauty. Realizing that "there is nothing sacred" (Dostoevsky, 1972-1990, 16: 330), as if following Nietzsche's demand, they experimentally test the idea of boundless and dangerous innocence ("everything is allowed"). At the same time, they discover the beauty of evil, the ecstasy from realizing one's own meanness and crossing the "line" - the divine and moral law. They are a kind of aestheticians, worshiping "aestheticism as gaining pleasure from the forbidden" (Gaidenko, 1997), who have found pleasure in both poles of beauty. Virtually overthrowing morality, they solve the metaphysical problem: "existence is either deceptive or eternal" (Camus, 1990: 81). The collapse, which invariably awaits these characters on their way of self-will, testifies that Nietzsche's version of overcoming morality in the "morality of the creative" (Jaspers, 2004: 242) and metaphysics in aesthetic phenomenalism, affirming the existence's deceptiveness, is excluded for Dostoevsky. In Dostoevsky's works, like in Nietzsche's, the morality is destructed "within the framework of the supermoral perspective" . However, these prospects differ significantly. For Dostoevsky and his characters with strengthened consciousness, there is no way of returning to the former unity of reason, morality and existence, but, driven by the need for higher thought and higher life, they are looking for a new breakthrough to the transcendent. The possibility of such a breakthrough for Dostoevsky is contained in the "wonderful and miraculous beauty" of the Christ's ideal, which lies in his moral unattainability. A single personal embodiment of the "ideal of Beauty" (Dostoevsky, 1972-1990, 29: 85 ), which is essentially supermoral in nature, and its rational incomprehensibility indicate the possibility of transcendental reality and open the door for a person to contact with it (Kuzubova, 2001: 138-144) ${ }^{2}$. However, the comparison of the alternative projects, proposed by Dostoevsky and Nietzsche, to overcome metaphysics as a moral interpretation of the world is a topic of a particular study.

\section{FOOTNOTES:}

1. The study of the foundations of Nietzsche's criticism of morality is one of the leading subjects in contemporary Nietzsche studies (Leiter, 1995: 113-145; Morrisson, 2003: 657-672; Kail, 2014: 214-233; Katsafanas, 2011: 170-192; Huddleston, 2015: 281-307). One of the tasks of this article is to reveal the role of the genealogy of morality in the destruction of metaphysics.

2. In this regard, it is difficult to agree with the K.G. Isupov's position, who interprets the metaphysics of Dostoevsky as genuine - medieval - realism, affirming the ontological identity of Beauty, Truth and Goodness; the disposition of Providence is realized in Beauty (Isupov, 2011: 68-87). However, the "sophiological" study of saving the world by Beauty is far from Orthodox Christianity and serves as a response to the dialectic of the "strengthened consciousness" that destroyed this classic synthesis after conducting fruitless searches in the world for the "teleology of God's providence".

\section{REFERENCES}

Adorno, T. (2011). Negativnaya dialektika [Negative dialectics]. Moscow: Akademicheskii proekt Publ., 506.

Buber, M. (1995). Dva obraza very [Two types of faith]. Moscow: Respublika Publ.

Camus, A. (1990). Buntuyuschii chelovek. Filosofiya. Politika. Iskusstvo [The Rebel-lious Man. Philosophy. Policy. Art]. Moscow: Politizdat Publ., 81.

Deleuze, G. (2003). Nitsshe i filosofiya [Nietzsche and philosophy]. Moscow: Ad Marginem Publ., 202.

Deleuze, G., Guattari, F. (1998). Chto takoe filosofiya? [Qu'est-ce que la philosophie? Les Èditions de Minuit]. St. Petersburg: Aletheia, 11.

Dostoevsky, F.M. (1972-1990). Polnoe sobranie sochinenii: V 30 tomakh [Complete works: In 30 volumes]. Leningrad: Nauka Publ. 
Elthaninoff, M. (2011). "Coupable devant tous et pour tout": Justice et culpabilite chez Dostoievski, Etudes: Rev. mens., 414(1), 77-87.

Gaidenko, P.P. (1997). Proryv k transtsendentnomu: Novaya ontologiya XX veka [Breakthrough to the transcendental: New ontology of the 20th century]. Moscow: Respublika Publ.

Guseinov, A.A. (2000). Etika i moral v sovremennom mire [Ethics and morality in the modern world], in Eticheskaia mysl [Ethical thought]. Moscow: IF RAN Publ., 1, 4-15.

Heidegger, M. (1993). Vremya i bytie [Sein und Zeit. Tübingen]. Moscow: Respublika Publ., 63-64.

Horuzhii, S.S. (2007). Krizis klassicheskoi evropeiskoi etiki v antropologicheskoi perspektive [The crisis of classical European ethics in anthropological perspective]. in Etika nauki [Ethics of science]. Moscow: IF RAN Publ., 85-97.

Huddleston, A. (2015). What is Enshrined in Morality? Understanding the Grounds for Nietzsche's Critique. An Interdisciplinary Journal of Philosophy, 58(3), 281-307.

Isupov, K.G. (2011). Dostoevsky's Transcendental Esthetic. Russian Studies in Philosophy, 50(3), 6887).

Jaspers, K. (1994) Smysl i naznachenie istorii [Meaning and purpose of history]. Moscow: Respublika Publ., 501.

Jaspers, K. (2004). Nitsshe. Vvedenie v ponimanie ego filosofstvovaniya [Nietzsche. Introduction to understanding his philosophizing]. St. Petersburg: Vladimir Dal Publ.

Kail, P.J.E. (2014). Genealogy' and the Genealogy. in Nietzsche's On the Genealogy of Morality: A Critical Guide (ed. S. May). Cambridge: Cambridge University Press, 214-233.

Katsafanas, P. (2011). The Relevance of History for Moral Philosophy: a Study of Nietzsche's Genealogy. in Nietzsche's On the Genealogy of Morality: A critical Guide (ed. S. May). Cambridge: Cambridge University Press, 170-192.

Kuzubova, T.S. (2001). Metafizicheskie miry Dostoevskogo i Nitsshe [The metaphysi-cal worlds of Dostoevsky and Nietzsche]. Ekaterinburg, 138-144.

Leiter, B. (1995). Morality in the pejorative sense: On the logic of Nietzsche's critique of morality. British Journal for the History of Philosophy, 3(1), 113-145.

Luft, E., Stenberg, D.G. (1991). Dostoevskii's specific influence on Nietzsche's preface to "Daybreak". Journal of the history of ideas, 52(3), 441-461.

Morrisson, I. (2003). Nietzsche's Genealogy of Morality in the Human, all too Human Series. British Journal for the History of Philosophy, 11(4), 657-672.

Nietzsche, F (1990). Sochineniya: V 2 tomakh [Works: In 2 volumes]. Moscow: Mysl Publ.

Nietzsche, F. (2005). Volya $k$ vlasti. Opyt pereotsenki vsekh tsennostei [The Will to Power. Experience of revaluation of all values]. Moscow: Kulturnaya revolyutsiya Publ, 238.

Nietzsche, F. (2010). Utrennyaya zarya: Mysli o moralnykh predrassudkakh. Morgenröte Gedanken über die moralischen Vorurteile [Daybreak: Thoughts on the prejudices of morality]. Harkov: Folio, 6.

Ricoeur, P. (2008). Konflikt interpretatsii. Ocherki o germenevtike [The conflict of in-terpretations. Essays on hermeneutics]. Moscow: Akademicheskii proekt Publ., 611.

Shestov, L. (1992). Kerkegor i ekzistentsialnaya filosofiya: Glas vopiyushchego $v$ pustyne [Kierkegaard and existential philosophy: A voice of crying in a desert]. Moscow: Progress-Gnozis Publ., 15 .

Shestov, L. (1993). Sochineniya: V 2 tomakh [Works: In 2 volumes]. Moscow: Nauka Publ. 2, p. 91. 